\title{
ANALISIS KURVA RESESI ALIRAN DASAR MENGGUNAKAN MODEL RESERVOIR LINIER PERANGKAT LUNAK RECESSION CURVE HYDROOFFICE PADA DAS WURYANTORO KABUPATEN WONOGIRI PROPINSI JAWA TENGAH
}

\author{
Bokiraiya Latuamury \\ Jurusan Kehutanan Fakultas Pertanian Universitas Pattimura, Ambon \\ Email:okky.environmentalscience@gmail.com \\ Sudarmadji dan Slamet Suprayogi \\ Jurusan Geografi Lingkungan Fakultas Geografi \\ Universitas Gadjah Mada
}

\begin{abstract}
The hydrograph recession curve expresses the theoretical relationship between the aquifer structure and the flow of groundwater flowing into the river basin channel. These theoretical relationships are often empirically depicted using the base flow recession curve. The hydrograph recession curve is commonly used to estimate the recessionary parameters, aquifer properties and to evaluate alternative hydrological hypotheses. The river basin hydrograph recession curve records the behavior of the relationship between the aquifer structure and its association with groundwater outflow to the river channel. This research was conducted with the aim: to analyze the characteristics of the baseflow recession based on the parameters and coefficients of the recession, and the shape of the individual recession curve and the master recession curve.

The characteristics of the baseflow recession to research sub-watershed have the recession curves tend to sloped, describing the water storage well enough. The parameter $Q 0$ (recession early), a and the recession constant Krb ranging from 0,80-0,90 for the individual and master recession curve in all three research sub-watershed. This calculation result indicates that the recession characteristics in three research sub-watershed have the condition of water storage is excellent, because they are supported by the aquifer characteristics dominated by the geological structures are more permeable (porous).
\end{abstract}

Keywords: baseflow recession characteristic; the parameters of recession; the individual's recession curve shape; the master recession curve.

\begin{abstract}
ABSTRAK
Kurva resesi hidrograf aliran sungai merupakan hubungan teoritis antara struktur akuifer dan aliran airtanah yang mengalir menuju saluran sungai. Hubungan teoritis ini sering digambarkan secara empiris menggunakan kurva resesi. Kurva resesi hidrograf digunakan untuk mengestimasi parameter resesi, sifat akuifer dan untuk mengevaluasi kondisi hidrologi DAS.Untuk itu, penelitian ini bertujuan untuk menganalisis kurva resesi aliran dasar sungai meliputi kurva resesi individu, dan kurva resesi master baik secara manual dan melalui pemrosesan algoritma genetika menggunakan model reservoir linier dari perangkat lunak hydrooffice paket recession curve (RC) 4.0. Hasil analisis kurva resesi individu menunjukkan bahwa karakteristik resesi aliran dasar di SubDAS Wuryantoro cenderung bervariasi, dengan nilai RMSE (root mean square error) < 0,001, dan dipertimbangkan mewakili bentuk kurva resesi individu di DAS penelitian. Hasil analisis kurva resesi individu dan kurva resesi master secara manual maupun melalui proses algoritma genetika memiliki nilai koefisien resesi adalah ( 0,80 dan 0,90$)$. Analisis
\end{abstract}


kurva resesi master secara algoritma genetika lebih optimal dibandingkan dengan kurva resesi master secara manual. Bentuk kurva resesi master yang landai menggambarkan kondisi simpanan air DAS lebih cukup tinggi, dan tersimpan dalam waktu yang lebih lama. Bentuk kurva resesi master juga menunjukkan karakteristik akuifer, terutama struktur geologi yang bersifat permeable (porous).

Kata Kunci: Analisis kurva resesi; Kurva resesi individu; Kurva resesi master, Simpanan air DAS.

\section{PENGANTAR}

Pendekatan kurva resesi secara luas merupakan suatu karakterisasi teoritis dari perilaku resesi hidrograf Daerah Aliran Sungai (DAS). Teori resesi hidrograf dimunculkan dari penelitian aliran airtanah (Dupuit 1863; Boussinesq, 1877; Maillet, 1905) dan sejak saat itu mendorong beragam pendekatan untuk karakterisasi hubungan antara aliran permukaan dan aliran airtanah selama periode aliran rendah (Tallaksen, 1995; Smakhtin, 2001). Penelitian resesi aliran dasar mendapat banyak perhatian, terutama penelitian yang fokus terhadap kuantitas debit airtanah maupun kualitas debit airtanah menuju saluran sungai.

Setiap Daerah Aliran Sungai (DAS) memiliki kurva resesi individu dan kurva resesi master. Kurva resesi master mencerminkan karakteristik penyimpanan DAS secara keseluruhan dan merupakan kombinasi sistem aliran sungai dan aliran airtanah yang respon terhadap kejadian hujan (Beven dan Kirkby, 1993). Jika cara menggabungkan seluruh rangkaian kurva resesi membentuk garis-garis kontinu yang relatif landai, maka bentuk kurva resesi master lebih landai. Kurva resesi yang mengelompok membentuk dua kurva resesi individu. Hal mengindikasikan bahwa ada dua sistem penyimpanan DAS yang berbeda dalam merespon curah hujan, masing-masing dapat digambarkan dengan persamaan linier terbaik untuk nilai K sebagai fungsi dari $\log \mathrm{Q}$. Kurva resesi master dengan kemiringan landai, menunjukkan korelasi yang sangat kuat antara waktu dan debit sungai mendekati 1, yang ditentukan dalam hari persiklus log.

Proses penyimpanan air dalam skala DAS, dicirikan dengan kurva resesi master, yaitu kurva resesi master berbentuk landau merupakan hasil dari penyimpanan aliran dasar yang tinggi dalam sistem aliran sungai dan airtanah. Sistem tersebut mencerminkan karakteristik DAS beberapa tahun berdasarkan besar-kecilnya sistem input curah hujan dalam jangka panjang. Sementara, kurva resesi master berbentuk curam, menunjukkan bahwa kapasitas penyimpanan jenuh beberapa hari. Kapasitas penyimpanan kecil, menunjukkan kemungkinan input curah hujan relatif kecil, terlokalisasi pada bagian DAS tertentu. Kondisi ini dibandingkan dengan potensi penyimpanan aliran sungai dan airtanah memiliki volume kecil, terutama bila dianggap penyimpanan depresi besar di DAS, dan fakta bahwa hanya sekitar 50\% DAS berkontribusi terhadap limpasan permukaan. Kurva resesi curam umumnya ditemukan selama musim kemarau, dengan resesi aliran dasar yang semakin menurun. Hal ini terutama berpengaruh signifikan pada daerah dengan muka airtanah dangkal dan vegetasi ekstensif, di mana pengeringan dari tanah lapisan atas dapat digantikan oleh pengangkutan kapiler airtanah (Szilagyi $d k k$., 2007).

Bentuk kurva resesi merupakan suatu segmen hidrograf, dan kurva resesi tersebut memiliki korelasi satu sama lain (Tallaksen, 1995). Hubungan fungsional ini harus dilengkapi dengan data yang memadai untuk memperoleh pernyataan kuantitatif (Eckhardt, 2008). Model resesi dapat dipilih antara pernyataan analitis yang dipilih apriori berdasarkan pertimbangan teoritis, atau ditentukan berdasarkan penilaian empiris. Persamaan resesi terpilih, disesuaikan untuk suatu set data tertentu dan kesesuaian visual subyektif terbaik. Sebuah prosedur teknik manual biasanya bersifat subyektif dan handal untuk kesalahan manusia. Sementara, metode otomatis lebih cepat, handal dan obyektif, serta digunakan untuk mengestimasi parameter resesi dan karakteristik resesi.

Perilaku debit sungai pada skala DAS diperkenalkan oleh Brutsaert (2008) melalui sebuah pendekatan untuk mengestimasi parameter resesi hidrograf dari kurva resesi, terutama debit sungai saat kondisi aliran 
dasar. Stoelzle $d k k_{.,}$(2013) menggambarkan cara pemilihan resesi hidrograf tunggal yang mempengaruhi persepsi mengenai perilaku simpanan dan keluaran aliran keluar. Berdasarkan uraian tersebut di atas, penelitian ini ini bertujuan untuk menganalisis karakteristik resesi aliran dasar melalui analisis kurva resesi individu, dan kurva resesi master melalui pemrosesan algoritma genetika dengan menggunakan teknik pemilihan dan pemrosesan secara otomatis dan debit time series yang relatif panjang sebagai representasi karaketristik resesi aliran yang optimal pada DAS Wuryantoro Kabupaten Wonogiri Propinsi Jawa Tengah.

Hasil penelitian analisis dan pemodelan kurva resesi aliran dasar sungai diharapkan berguna dalam banyak bidang perencanaan dan manajemen sumberdaya air antara lain: (1) dalam peramalan aliran dasar untuk pengelolaan irigasi, penyediaan air, pembangkit listrik tenaga air maupun pengenceran limbah; (2) berperan dalam pemodelan matematika untuk kalibrasi, atau sebagai input untuk pemodelan curah hujan-limpasan- aliran dasar; (3) berperan dalam analisis hidrograf resesi untuk pemisahan grafis komponen aliran yang berbeda; dan (4) berperan dalam analisis frekuensi untuk estimasi statistik aliran dasar dalam studi aliran dasar regional sampai dengan indeks kapasitas penyimpanan air DAS.

\section{Metode}

\section{Waktu dan Lokasi}

Penelitian ini dilaksanakan di DAS Wuryantoro Kabupaten Wonogiri Provinsi Jawa Tengah. Pencatatan debit harian selama kurun waktu dari 1 Januari 2000 - 31 Desember 2010. DAS ini Keduang dipertimbangkan untuk diteliti karena kelengkapan data SPAS (Stasiun Pengamatan Aliran Sungai) dengan debit harian yang layak untuk analisis kurva resesi aliran dasar. Lokasi SPAS terletak pada koordinat UTM yakni X 483012,04 dan Y 9128720,68 dengan luas DAS 17,78 km².

\section{Prosedur penelitian}

Penelitian ini menggunakan perangkat lunak hydrooffice 12.0 (http://hydrooffice. org) paket Recession Curve (RC) 4.0 (Gregor dan Malik, 2010 dan 2012) untuk menganalisis karakteristik resesi aliran dasar pada DAS Wuryantoro Propinsi Jawa Tengah. Data debit harian selama kurun waktu 1 Januari 2000 sampai dengan 31 Desember 2010) digunakan untuk pemilihan dan pengolahan segmen resesi serta analisis kurva resesi individu dan kurva resesi master, dengan melakukan kalibrasi model resesi adalah model reservoir linier (Persamaan 1) (Boussinesq 1877; Maillet 1905):

$Q=Q_{0} e^{-k t}$

dimana: Q0 =debit awal resesi, $\mathrm{k}=$ koefisien resesi. Paraeter Q0 dan k, dikalibrasi dalam model reservoir linier.

Model reservoir linier dipertimbangkan karena ketersediaan time series debit harian relatif pendek 10 tahun seperti yang disyaratkan model. Persamaan resesi dipilih atas dasar pertimbangan teoritis, penilaian empiris, dan disesuaikan dengan dataset dan kesesuaian visual terbaik.

\begin{tabular}{lll}
\hline \multicolumn{1}{c}{ Model Konseptual } & Persamaan fungsi resesi & \multicolumn{1}{c}{ Tipe Simpanan } \\
\hline $\begin{array}{l}\text { Linear reservoir (Boussinesq } \\
\text { 1877; Maillet 1905) }\end{array}$ & $Q=Q_{0} e^{e-k t}$ & $\begin{array}{l}\text { Persamaan Depuit-Boussinesq } \\
\text { Untuk Simpanan umum dalam periode } \\
\text { resesi relatif pendek }\end{array}$ \\
\hline $\begin{array}{l}\text { Horton double exponential } \\
\text { model (Horton 1933) }\end{array}$ & $Q=Q_{0} e^{e-\alpha_{2} t^{m}}$ & $\begin{array}{l}\text { Model reservoir linier untuk transformasi } \\
\text { simpanan umum }\end{array}$ \\
\hline Exponential reservoir & $Q=Q_{0} /\left(1+\phi Q_{0} . t\right)$ & $\begin{array}{l}\text { Model untuk konduktivitas hidraulik } \\
\text { tanah yang diasumsikan menurun secara } \\
\text { eksponensial terhadap kedalaman airtanah }\end{array}$ \\
\hline
\end{tabular}




\begin{tabular}{|c|c|c|}
\hline Model Konseptual & Persamaan fungsi resesi & Tipe Simpanan \\
\hline $\begin{array}{l}\text { Power-law reservoir } \\
\text { (Brutsaert and Nieber 1977; } \\
\text { Hall 1968) }\end{array}$ & $\begin{array}{l}Q=Q_{0} /(1+\mu t)^{\rho} \\
\rho=\beta /(1-\beta) \\
\mu=\alpha^{1 / \beta)}(\beta-1) Q_{0}^{\beta-1) \beta}\end{array}$ & $\begin{array}{l}\text { Model untuk mataair dan akuifer }(p=2) \text {, } \\
\text { kelembaban tanah, persamaan resesi } \\
\text { dimodelkan menggunakan }(\rho \approx 1,67 \mathrm{I} \text {; } \\
\text { Wittenberg, } 1994\end{array}$ \\
\hline $\begin{array}{l}\text { Dupuit-Boussinesqov } \\
\text { aquifer storage (Boussinesq } \\
\text { 1904) }\end{array}$ & $Q=Q_{0} /\left(1+\alpha_{3} t\right)^{-2}$ & $\begin{array}{l}\text { Kasus khusus untuk akuifer airtanah } \\
\text { dangkal }\end{array}$ \\
\hline $\begin{array}{l}\text { Hyperbola reservoir (Toebes } \\
\text { Strang, 1964) }\end{array}$ & $Q=\alpha_{1} t^{-v}+b$ & Lelehan salju, danau \\
\hline $\begin{array}{l}\text { Constant reservoir (Toebes } \\
\text { Strang, 1964) }\end{array}$ & $Q=\alpha$ & $\begin{array}{l}\text { Simpanan airtanah luas, aliran sungai } \\
\text { konstan dengan periode yang sangat } \\
\text { panjang }\end{array}$ \\
\hline $\begin{array}{l}\text { Turbulent model } \\
\text { (Kullman 1990) }\end{array}$ & $Q=Q_{0}(1-\beta t)$ & Akuifer Karst \\
\hline $\begin{array}{l}\text { Hyperbolic model } \\
\text { (Kovács 2003) }\end{array}$ & $Q=Q_{0}(1+\alpha t)^{n}$ & Akuifer Karst \\
\hline
\end{tabular}

$\mathrm{Q}=$ debit, $\mathrm{t}=$ waktu permulaan resesi, $\mathrm{Q}_{0}=$ waktu untuk $\mathrm{t}=0 ; \mathrm{k}, \mathrm{n}, \mathrm{m}, \mathrm{\alpha}, \beta, \mu, \Phi, \mathrm{\gamma}, \varphi=$ parameter yang diturunkan dari kalibrasi model

Kurva resesi individu dan kurva resesi master dibuat secara manual dan/ atau secara otomatis. Memindahkan kurva resesi individu pada timeline (sumbu horisontal), sehingga membentuk satu kurva resesi master (Gregor dan Malik, 2012). Hasil kurva resesi master yang dibuat dari data input. Menciptakan kurva resesi master difokuskan terutama untuk menjelaskan perjalanan resesi dari kondisi aliran dari sistem hidrologi (DAS) dan/ atau struktur hidrogeologi pada saat deplesi, kemudian mencatat aliran terendah. Rezim resesi mencirikan aliran yang tidak terpengaruh limpasan oleh parameter dinamis seperti parameter meteorologi dan iklim di daerah tangkapan air, tetapi hanya bergantung pada sifat hidrolik dari sistem hidrologi dan/ atau struktur hidrogeologi.

Seluruh proses membuat kurva resesi master secara otomatis diawali dengan segmentasi kurva resesi terpilih ke dalam segmen pendek. Metode resesi didasarkan pada kenyataan bahwa untuk membuat kurva resesi master, kurva resesi terpilih tidak menggunakan seluruh durasinya karena setiap kurva resesi berasal dari situasi hidrologi yang berbeda dan unik, dan setiap kurva resesi adalah unik. Semua kurva resesi terpotong menjadi segmen pendek, yang menggambarkan perubahan resesi dalam jangka waktu hanya beberapa hari. Kurva resesi individu terpotong secara manual atau secara otomatis.

Dalam tahap pengembangan dan pengujian kurva resesi, segmentasi otomatis paling sering digunakan. Untuk menjalankan metode segmentasi otomatis, tahapan segmentasi diatur dalam hari (atau minggu), dengan durasi resesi $\mathrm{N}$ hari atau $\mathrm{N}$ minggu. Input optimal untuk segmen resesi secara otomatis (panjang durasi dari suatu segmen) adalah empat pengukuran berturut-turut (4 hari atau minggu) observasi. Setelah semua segmen individu terpilih selesai, tahap berikutnya melakukan pemrosesan pengolahan kurva resesi terpilih. Untuk memperoleh hasil kurva resesi master yang akurat, perlu memperoleh jumlah segmen yang cukup untuk setiap interval debit, dari nilai pengukuran tertinggi sampai terendah. Syarat distribusi normal dari data time series membantu proses analisis kurva resesi master.

Analisis visual distribusi frekuensi debit dapat dilihat pada tombol Histogram, yang menunjukkan frekuensi relatif dari nilai debit terukur pada bagian yang berbeda. Setelah menyesuaikan data, distribusi frekuensi dari 
nilai-nilai debit lebih seragam. Ini berarti bahwa untuk menjalankan algoritma genetik, jumlah siklus evolusi yang sedikit diperlukan agar algoritma evolusioner berjalan lebih cepat, sebagaimana jumlah data yang lebih kecil diproses lebih cepat. Selama pengujian dan kinerja algoritma oleh penulis, ditemukan bahwa untuk akurasi yang cukup dari estimasi kurva resesi master yang dirakit secara otomatis adalah tepat dengan menjalankan algoritma minimal tiga kali, pada berbagai nilai parameter (terutama mutasi), dan memilih solusi terbaik.

\section{HASIL DAN PEMBAHASAN Parameter dan koefisien resesi dari segmen resesi individu}

Hasil kalibrasi model reservoir linier memperoleh parameter awal resesi $\left(\mathrm{Q}_{0}\right)$ untuk
SubDAS Wuryantoro dari total 80 segmen resesi memiliki nilai parameter $\mathrm{Q}_{0}$ berkisar antara (2,71 - 37,10 $\mathrm{m}^{3} /$ det $)$ dengan nilai median 6,69 $\mathrm{m}^{3} /$ det, dan parameter $\mathrm{Q}_{0}$ per tahun berkisar antara $\left(2,71-7,59 \mathrm{~m}^{3} /\right.$ det $)$ dengan nilai median $5,32 \mathrm{~m}^{3} /$ det. Kombinasi parameter $\mathrm{Q}_{0^{\prime}} \mathrm{a}$, konstanta resesi dengan nilai residual (RMSE) bervariasi selama kurun waktu penelitian.

Perhitungan nilai a untuk SubDAS Wuryantoro berkisar antara $(0,041-0,199)$ dan nilai median 0,113 , dan nilai a per tahun periode 2000 - 2010 berkisar antara $(0,044-0,158)$ dan median 0,106. Berdasarkan hasil a untuk total segmen resesi di SubDAS penelitian, dilakukan perhitungan konstanta resesi $(\mathrm{Krb})$ SubDAS Wuryantoro dengan nilai Krb berkisar antara 0,8196 - 0,9598 dengan median 0,8932 disajikan pada Tabel 1 dan Lampiran 1.

Tabel 1. Perhitungan Parameter dan Konstanta Resesi Periode 2000-2010

\begin{tabular}{l|l|l|l|l|l|l|l|l}
\hline Tahun & \multicolumn{1}{|c|}{ Tanggal } & Durasi (Hari) & Q_0 & a & Krb & Q-Obs & Q-Cal & RMSE \\
\hline 2000 & 21 jul - 1 Agust 2000 & 11 & 7.59 & 0.10 & 0.906 & 4.62 & 4.41 & 0.1343 \\
2001 & 19-29 Jul 2001 & 10 & 6.81 & 0.16 & 0.854 & 3.09 & 3.09 & 0.0898 \\
\hline 2002 & 13 - 24 Agust 2002 & 11 & 5.90 & 0.04 & 0.957 & 4.66 & 4.63 & 0.0318 \\
\hline 2003 & 16-26 Agust 2003 & 10 & 5.32 & 0.11 & 0.893 & 3.18 & 3.02 & 0.0925 \\
\hline 2004 & 5-15 Jul 2004 & 10 & 4.35 & 0.13 & 0.877 & 2.31 & 2.26 & 0.0581 \\
\hline 2005 & 12-22 Okt 2005 & 10 & 6.69 & 0.11 & 0.897 & 3.90 & 3.88 & 0.0404 \\
\hline 2006 & 9-19 Jul 2006 & 10 & 4.22 & 0.08 & 0.920 & 2.79 & 2.79 & 0.0217 \\
\hline 2007 & 15 - 25 Jul 2007 & 10 & 3.90 & 0.11 & 0.893 & 2.27 & 2.22 & 0.0462 \\
\hline 2008 & 8-19 Des 2008 & 11 & 6.65 & 0.11 & 0.899 & 3.76 & 3.72 & 0.0469 \\
\hline 2009 & $10-21$ Jul 2009 & 11 & 3.25 & 0.09 & 0.917 & 2.10 & 2.02 & 0.0770 \\
\hline 2010 & $16-27$ Agust 2010 & 11 & 2.71 & 0.05 & 0.956 & 2.12 & 2.12 & 0.0141 \\
\hline
\end{tabular}

Sumber : Analisis kurva resesi Recession curve Hydrooffice 12.0, 2000 s.d 2010

Hasil perhitungan Krb per tahun selama 2000 - 2010 untuk SubDAS Wuryantoro memiliki nilai Krb berkisar antara 0,8538 - 0,9570 dengan median 0,8994. Nilai parameter, koefisien, dan konstanta resesi untuk SubDAS Wuryantoro merepresentasikan kondisi resesi aliran dasar optimal dalam kapasitas penyimpanan aliran relatif tinggi. Hasil ini sesuai dengan penelitian Nathan dan McMohan (1997) yang menyatakan bahwa konstanta resesi \pm 0,80 s.d 0,90 memiliki kapasitas penyimpanan aliran sangat tinggi.

\section{Bentuk Kurva Resesi Individu dari DAS Penelitian}

Bentuk kurva resesi individu untuk Wuryantoro selama periode 2000 s.d 2010 memperlihatkan bentuk kurva resesi individu aliran dasar yang cukup variatif, yang mencerminkan proses aliran keluar yang berbeda dalam masing-masing segmen resesi sebagai representasi karakteristik resesi aliran dasar sungai. Kurva resesi aliran dasar pada Gambar 2 memperlihatkan kurva resesi 
aliran dasar dengan sumbu absis (sumbu-x) adalah waktu (dalam hari) dan sumbu ordinat (sumbu-y) adalah debit harian $\left(\mathrm{m}^{3} /\right.$ detik). Kurva resesi aliran dasar yang dianalisis meliputi peristiwa resesi selama kurun tahun 2000 s.d 2010, kemudian peristiwa yang terpilih divalidasi dengan peristiwa resesi pengukuran, dan hasil verifikasi kurva resesi terpilih dengan nilai RMSE terkecil yang digunakan sebagai representasi karakteristik resesi aliran dasar di SubDAS Wuryantoro.

Variasi kurva resesi individu secara keseluruhan untuk SubDAS Wuryantoro, yakni dari total 80 segmen resesi diperoleh kisaran nilai $\mathrm{Krb} \pm 0,90$ sebanyak 33 segmen resesi atau 40,74\%, dan nilai Krb berkisar \pm 0,80 sebanyak 48 segmen resesi atau 59,26\%. Hasil
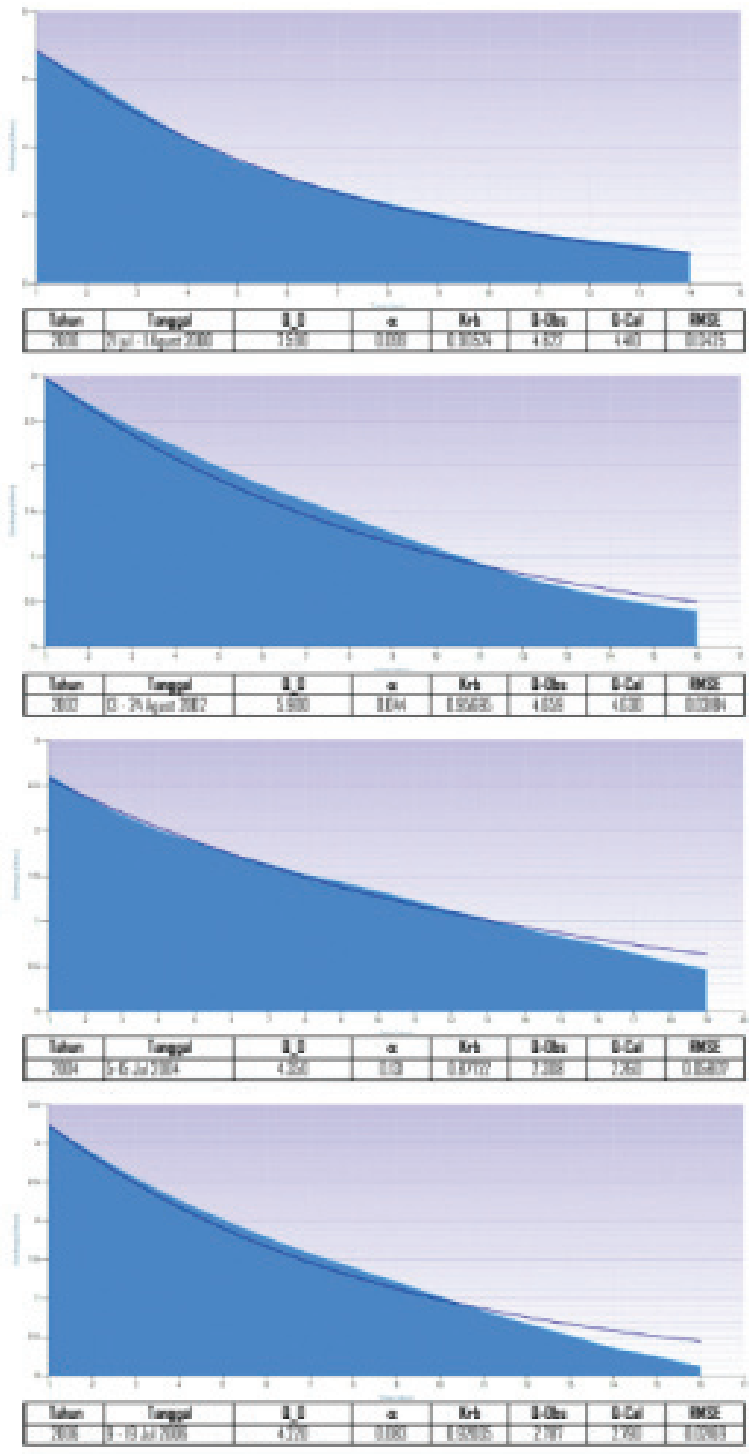

persentase nilai Krb untuk SubDAS penelitian menunjukkan bahwa kurva resesi individu berada pada kirasan Krb 0,80 - 0,90 sesuai dengan kriteria nilai konstanta resesi Nathan dan McMohan (1997) menyatakan bentuk kurva resesi aliran dasar sangat baik. Hasil penelitian ini juga mendekati penelitian dari Tallaksen (1997) yang menyatakan bahwa koefisien resesi yang tinggi memiliki kemiringan kurva resesi semakin landai, dan sebaliknya semakin kecil koefisien resesi, kemiringan kurva resesi semakin curam. Bentuk kurva resesi landai memiliki kondisi simpanan aliran dasar yang baik dan berlangsung relatif lama, sebaliknya bentuk kurva resesi curam memiliki kondisi simpanan aliran dasar yang cenderung boros dan berlangsung cepat.
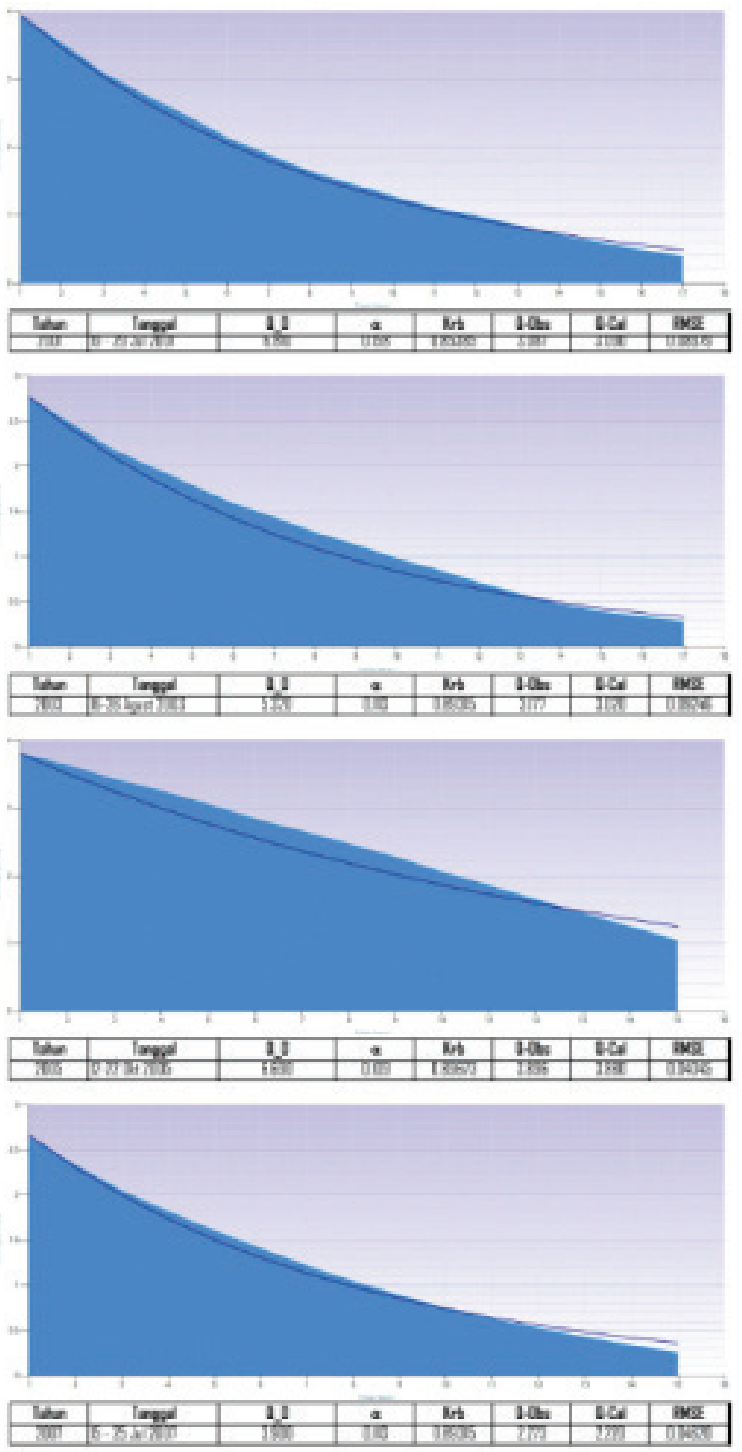

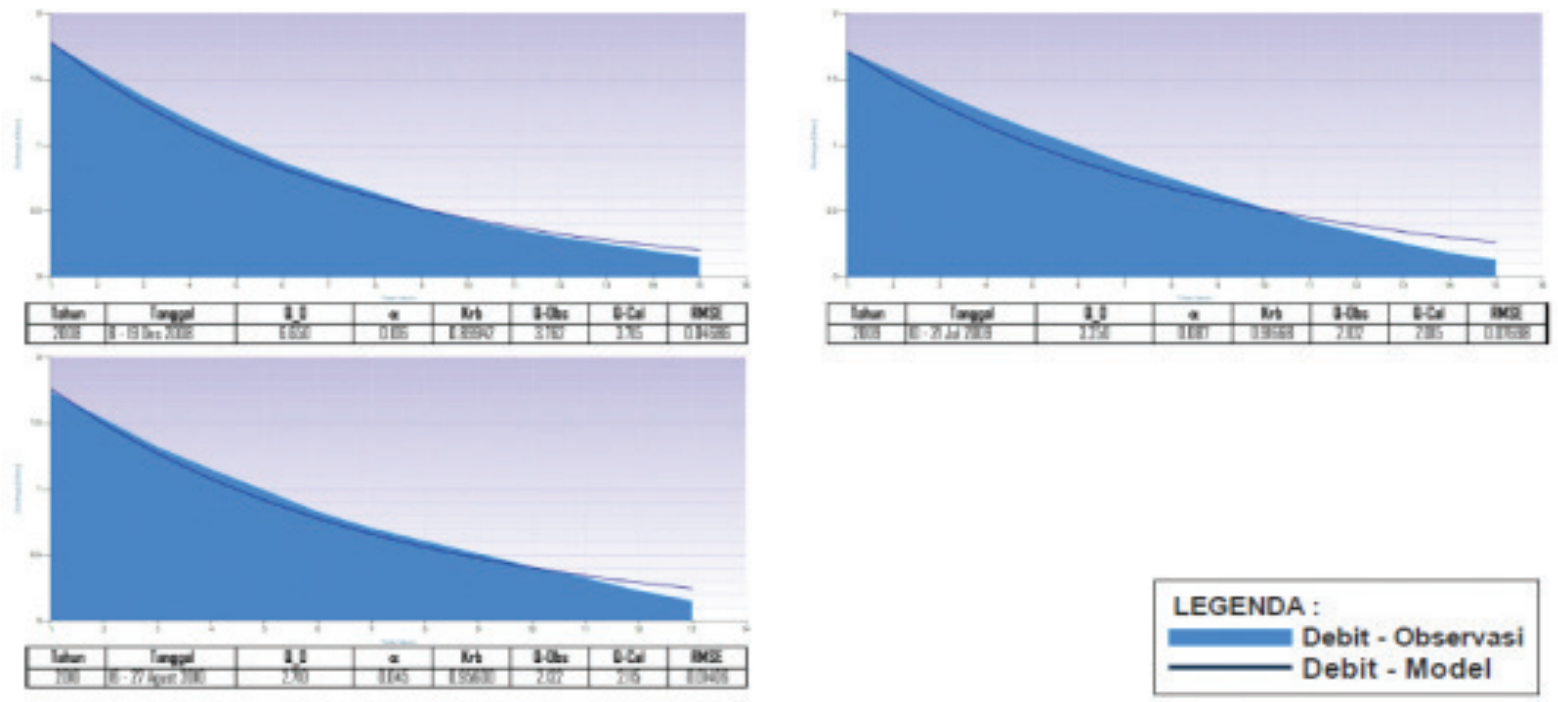

Gambar 1. Variasi kurva resesi individu SubDAS Wuryantoro periode 2000 - 2010

\section{Bentuk Kurva Resesi Master secara Manual}

Hasil analisis kurva resesi master secara manual untuk SubDAS Wuryantoro memiliki kombinasi parameter awal resesi Q0 $(9,99)$, nilai a $(0,075)$ dan nilai konstanta resesi Krb $(0,925)$, artinya bahwa kurva resesi aliran dasar cenderung membentuk garis kurva resesi landai. Bentuk kurva resesi landai menggambarkan bahwa karateristik resesi aliran dasar di SubDAS Wuryantoro memiliki kapsitas simpanan aliran sangat tinggi 92,5\%. Kombinasi parameter Q0, a dan Krb menunjukkan bahwa parameter Qo untuk SubDAS penelitian berkisar pada kisaran resesi aliran dasar yang optimum mengikuti hasil penelitian konstanta resesi oleh Nathan dan McMohan, (1997) bahwa konstanta resesi berkisar diatas 0,90 memiliki bentuk kurva resesi landai dan kondisi resesi aliran dasar skala DAS memiliki kapasitas penyimanan aliran yang optimum sebagaimana disajikan pada Gambar 3.

Rangkaian kurva resesi yang membentuk garis-garis kontinu yang relatif landai, memiliki bentuk kurva resesi master lebih landai. Kurva resesi yang mengelompok akan membentuk dua kurva resesi individu atau lebih. Hal ini mengindikasikan bahwa ada dua sistem penyimpanan DAS yang berbeda dalam merespon curah hujan, yang masing-masing dapat digambarkan dengan persamaan linier terbaik untuk nilai K sebagai fungsi dari $\log$ Q.

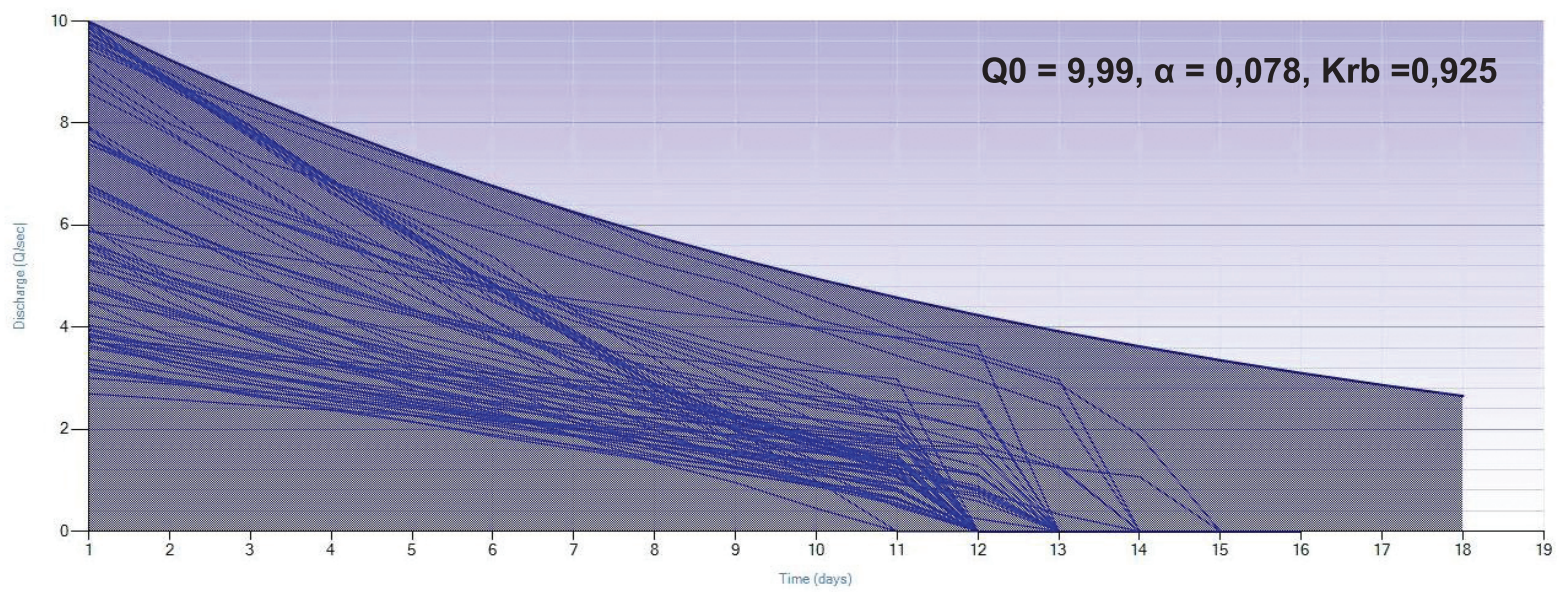

Gambar 2. Bentuk kurva resesi master secara manual DAS penelitian 
Kurva resesi master dengan kemiringan landai, menunjukkan korelasi yang sangat kuat antara waktu dan debit. Terkait dengan proses penyimpanan air dalam skala DAS, dicirikan dengan kurva resesi master. Kurva resesi master berbentuk landai adalah hasil dari penyimpanan aliran dasar yang tinggi dalam sistem aliran sungai dan airtanah. Sistem tersebut mencerminkan karakteristik DAS beberapa tahun berdasarkan besarkecilnya sistem input curah hujan dalam jangka panjang. Sebaliknya, kurva resesi master berbentuk curam, menunjukkan bahwa kapasitas penyimpanan jenuh beberapa hari. Kapasitas penyimpanan kecil, menunjukkan kemungkinan input curah hujan relatif kecil, terlokalisasi pada bagian DAS tertentu. Kondisi ini dibandingkan dengan potensi penyimpanan aliran sungai dan airtanah memiliki volume kecil, terutama bila dianggap penyimpanan depresi besar di DAS, dan fakta bahwa hanya sekitar 50\% DAS berkontribusi terhadap limpasan permukaan (Szilagyi et el., 2007).

\section{Kurva resesi master dari proses algoritma genetika}

Hasil pemrosesan evolusi dan solusi terbaik dari keempat parameter siklus evolusi adalah parameter number of generation (NG) ditetapkan 20, number of individu (NI) ditetapkan 10, Cross of probability 0.90, maximum length of master recession curve (ML MRC) 25, dan maximal dispersion of mutation 10. Visualisasi hasil solusi terbaik (best solution) untuk SubDAS Wuryantoro disajikan pada Gambar 3, menunjukkan pola resesi yang menumpuk dan cenderung bergerak ke kanan.

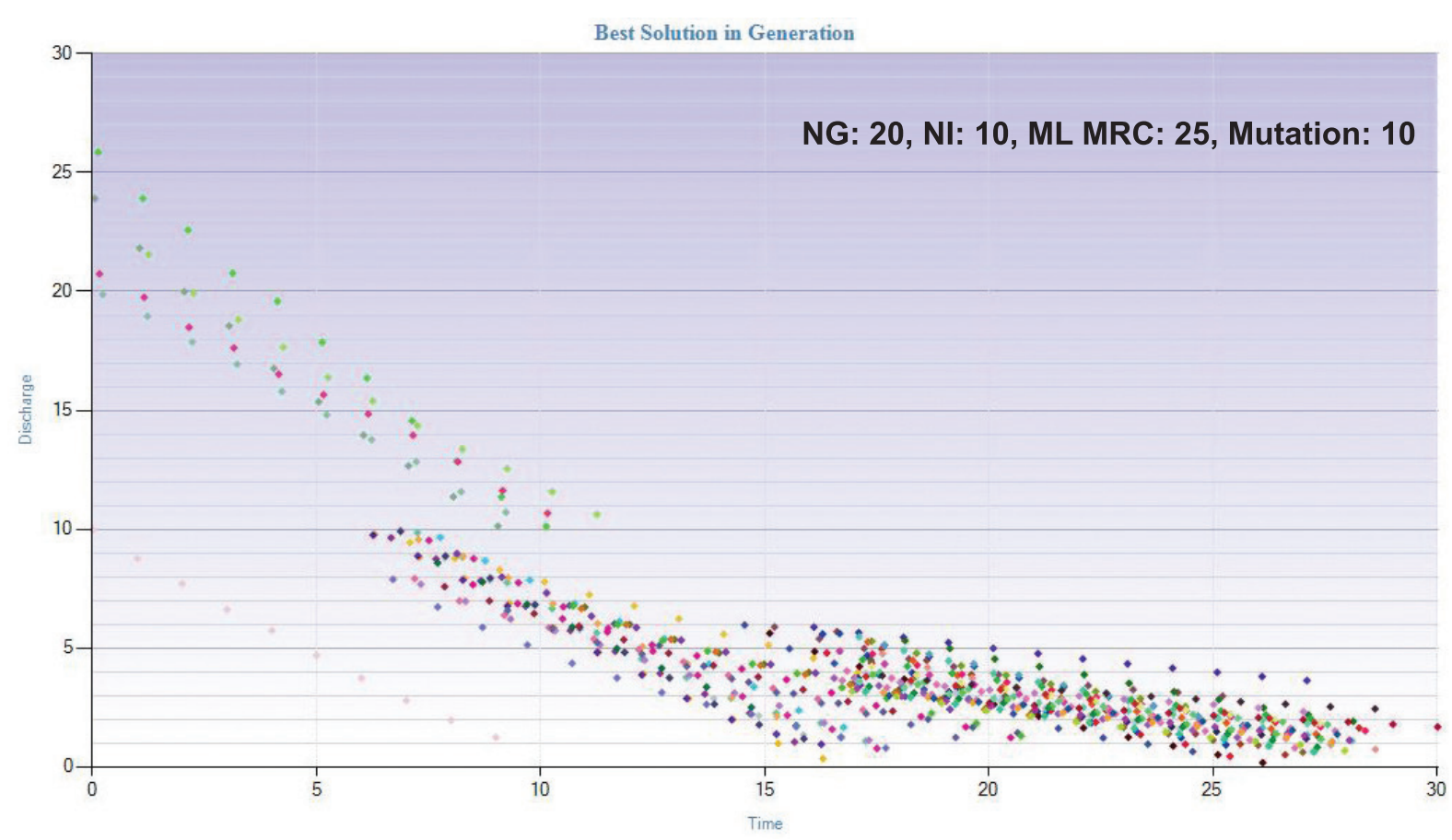

Gambar 3. Visualisasi solusi terbaik (best solution) dalam generasi algoritma genetika

Kinerja algoritma dari solusi terbaik yang ditampilkan menunjukkan bahwa solusi terbaik dari kurva resesi master yang optimal untuk Wuryantoro. Pengujian kinerja algoritma dilakukan untuk memperoleh hasil akurasi yang cukup optimum dalam melakukan estimasi kurva resesi master yang dirakit secara otomatis, sehingga memperoleh hasil estimasi yang akurat. Kinerja algoritma evolusi dapat diperlihatkan dengan pengembangan dispersi solusi dalam siklus evolusional. Waktu berjalan dari generasi algoritma tergantung pada 
jumlah segmen yang dipilih dari kurva resesi, jumlah siklus evolusi, sejumlah solusi solusi paralel (individu), dan pada parameter panjang maksimum kurva resesi master.

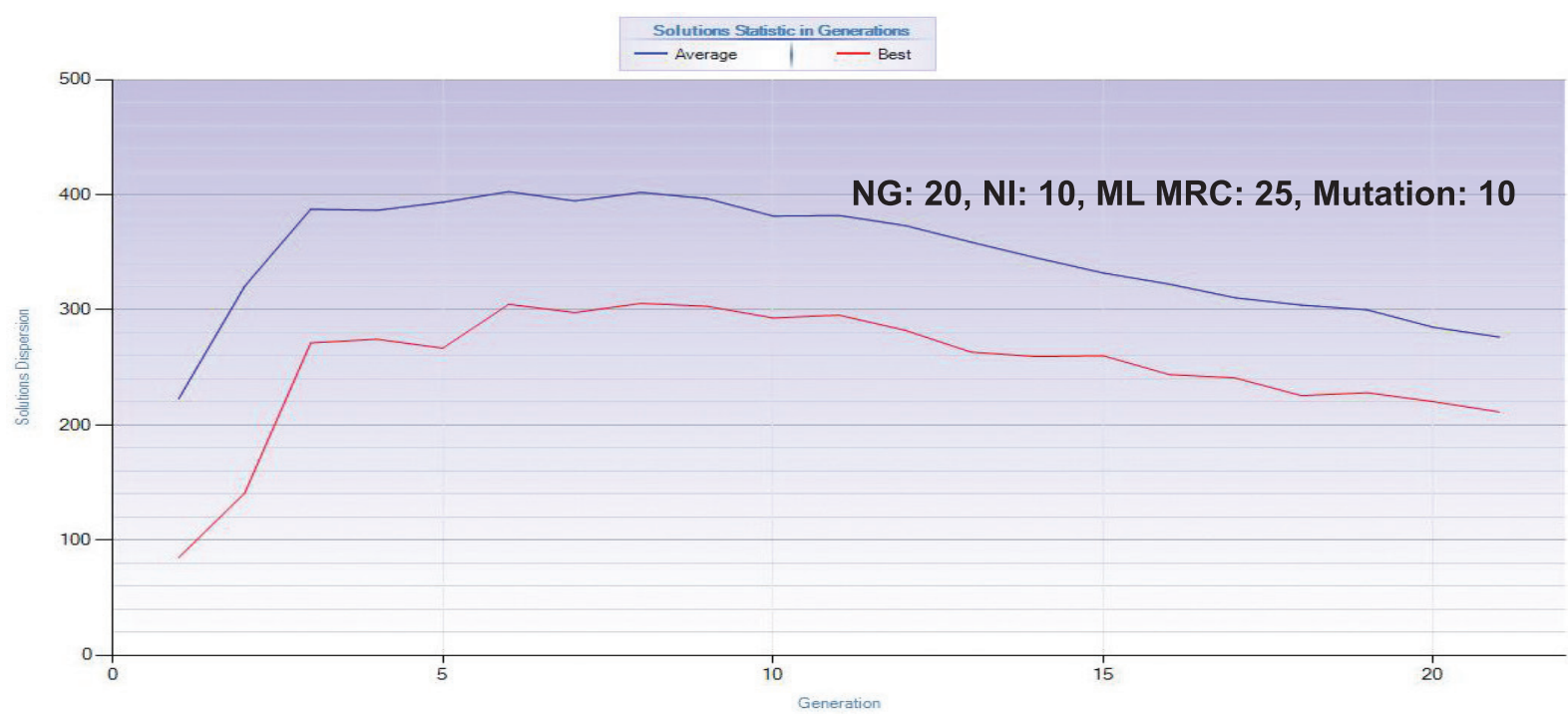

Gambar 4. Pengembangan dispersi solusi dalam siklus evolusional DAS penelitian

Hasil pengembangan disperse solusi dari siklus evolusi di SubDAS Wuryantoro memiliki disperse rata-rata (garis biru) yang optimal pada generasi 3 (tiga) dan solusi terbaik 390, dan disperse terbaik (garis magenta merah) pada generasi 3 (tiga) dan solusi terbaik 270 . Hasil disperse solusi menunjukkan hasil yang optimum. Hasil evolusi dan solusi terbaik yang optimal ini, kemudian dilakukan analisis lanjutan untuk memperoleh optimalisasi parameter dan koefisien kurva resesi master secara algoritma genetika yang lebih akurat.
Optimalisasi parameter dan koefisien resesi kurva resesi master secara algoritma genetika untuk SubDAS penelitian, yakni memiliki nilai parameter Qo $(30,76$, nilai a $(0,075)$ dan konstanta resesi $(0,928)$. Bentuk kurva resesi master melalui proses algoritma genetika menunjukkan bahwa bentuk kurva resesi SubDAS Wuryantoro relatif lebih landai dengan nilai konstanta resesi $\pm 0,90$; artinya bahwa kurva resesi master secara algoritma genetika untuk SubDAS Wuryantoro memiliki simpanan aliran dasar sangat tinggi disajikan pada Gambar 5.

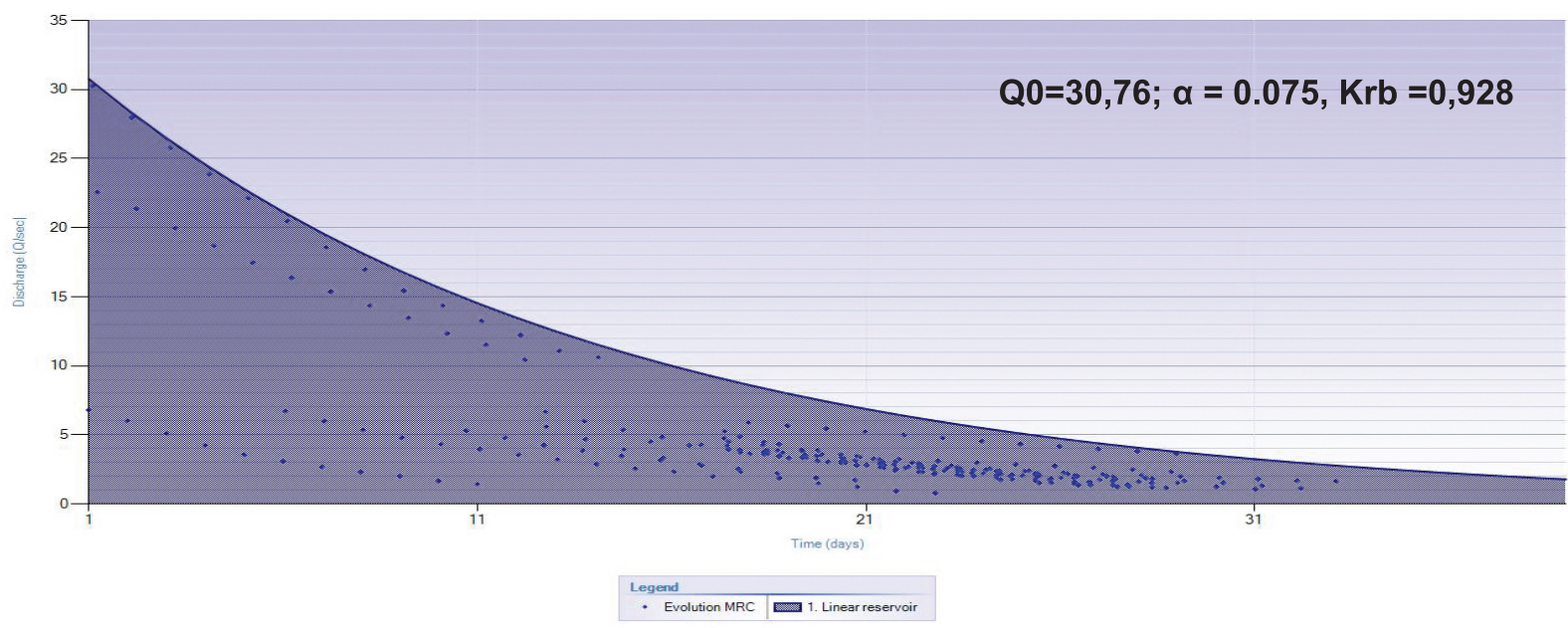

Gambar 5. Hasil algoritma genetik untuk urva resesi master di SubDAS penelitian 
Visualisasi kurva resesi master secara algoritma genetika menunjukkan bahwa distribusi titik data bergeser ke kanan dan cenderung menumpuk. Bentuk kurva resesi aliran dasar untuk SubDAS Wuryantoro relatif landai, memiliki kondisi resesi lebih optimal, yakni simpanan aliran dasar lebih besar dan cenderung lebih lambat. Bentuk kurva resesi memiliki tren lebih landai mendekati hasil analisis kurva resesi individu dan kurva resesi master secara manual, yakni bentuk kurva resesi lebih landai antar- peristiwa resesi dan peristiwa resesi antar- SubDAS penelitian, di mana secara teoritis lebih dipengaruhi oleh karakteristik akuifer dari SubDAS penelitian.

\section{Keterkaitan Resesi Aliran dan Karakteristik Akuifer Batuan DAS Penelitian}

Hubungan antara geologi dan resesi aliran dasar sering dilaporkan, tetapi penelitianpenelitian sebelumnya hanya terbatas pada deskripsi kualitatif. Vogel dan Kroll (1992) mengembangkan persamaan regresi dengan merumuskan model DAS konseptual untuk aliran dasar, dan memperluas model sederhana dari akuifer aliran dasar sungai untuk skala DAS. Karakteristik material penyusun geologi SubDAS penelitian mendukung hasil karakterisasi resesi aliran dasar sungai. Formasi semilir tersusun oleh tufa, breksi, batuapung dasitan tufa, serpih, formasi mandalika tersusun atas Breksi aneka bahan batupasir, batulanau dan batulempung bersisipan batugamping, napal pasiran, batupasir kerikilan, berbatuapung, setempat breksi gunungapi, dan Formasi Wonosari tersusun atas Aglomerat bersisipan batu asir tufaan dan batupasir kasar, breksi aglomerat, kayu terkersikan, bongkah tufa terkersikan. Keberadaan dataran alluvial karst dimungkinkan berpengaruh besar terhadap jumlah simpanan air DAS. Sedimentasi material alluvial yang berasal dari hulu dengan material vulkanik memungkinkan adanya endapan alluvium yang cukup tebal, sehingga menghasilkan peningkatan infiltrasi dan simpanan aliran dasar, sebagaimana disajikan pada Lampiran 2.

Suplai air ke tubuh sungai sebagai aliran dasar dipengaruhi oleh nilai porositas material penyusunnya. Porositas batuan sangat mempengaruhi imbuhan suatu sistem air tanah, sehingga besarnya tampungan air tanah sangat dipengaruhi oleh kondisi porositas tersebut. Dalam proses pergerakan air secara vertikal, porositas memegang peranan penting dalam recharge air tanah. Karakteristik batuan dalam mempengaruhi pergerakan air diketahui dari daya hantar hidrolik (hydraulic conductivity) batuan. Todd (1980) menyatakan bahwa daya hantar hidrolik merupakan ukuran permeabilitas dari medianya. Identifikasi jenis batuan dominan pada skala DAS dilakukan untuk mengetahui karakteristik hidrogelologi, terutama yang berkaitan dengan kemampuannya dalam meloloskan air (permeabilitas)

\section{LAMPIRAN}

Lampiran 1. Perhitungan parameter Q0, koefisien resesi, debit observasi dan debit terhitung, dan RMSE model menggunakan Recession Curve Hydrooffice 12.0 untuk SubDAS Wuryantoro

\begin{tabular}{|c|c|c|c|c|c|c|c|c|c|}
\hline $\mathrm{RC}$ & Awal & Akhir & Durasi (Hari) & 0,0 & $a$ & Konstanta rescsi & Q.06s & Q-caleulated & RMSE \\
\hline 1 & $1 / 5 / 2000$ & $1 / 17 / 2000$ & 12 & 22.280 & 0.064 & 0.9380 & 15.344 & 15.950 & 0.29246 \\
\hline 2 & $2 / 5 / 2000$ & $2 / 18 / 2000$ & 13 & 37.710 & 0.069 & 0.9333 & 25.674 & 24.100 & 1.09571 \\
\hline 3 & $3 / 7 / 2000$ & $3 / 17 / 2000$ & 10 & 23.490 & 0.084 & 0.9194 & 15.527 & .400 & 0.15395 \\
\hline 4 & $5 / 12 / 2000$ & $5 / 22 / 2000$ & 10 & 20.470 & 0.082 & 0.9213 & 15.151 & 14.700 & 0.31930 \\
\hline 5 & $7 / 21 / 2000$ & $8 / 1 / 2000$ & $\|$ & 7.590 & 0.099 & 0.9057 & 4.622 & 4.410 & 0.13425 \\
\hline 6 & $2 / 13 / 2001$ & $2 / 27 / 2001$ & 14 & 30.330 & 0.083 & 0.9204 & 17.775 & 17.700 & 0.20714 \\
\hline 7 & $3 / 1 / 2001$ & $3 / 13 / 2001$ & 12 & 22.690 & 0.065 & 0.9371 & 15.881 & 15.900 & 0.22653 \\
\hline 8 & $6 / 9 / 2001$ & $6 / 20 / 2001$ & $\|$ & 9.240 & 0.191 & 0.8261 & 4.135 & 3.560 & 0.60237 \\
\hline 9 & $7 / 19 / 2001$ & $7 / 29 / 2001$ & 10 & 6.810 & 0.158 & 0.8538 & 3.087 & 3.090 & 0.08979 \\
\hline
\end{tabular}


Lampiran 1 (Lanjutan)

\begin{tabular}{|c|c|c|c|c|c|c|c|c|c|}
\hline $\mathrm{RC}$ & Awal & Akhir & Durasi (Hari) & 0,0 & $a$ & Konstanta resesi & Q.0hs & Q-ealeulated & RMSE \\
\hline 10 & $1 / 7 / 2002$ & $1 / 20 / 2002$ & 13 & 20.820 & 0.063 & 0.9389 & 15.661 & 15.200 & 0.36351 \\
\hline$\|$ & $2 / 16 / 2002$ & $2 / 28 / 2002$ & 12 & 28.110 & 0.080 & 0.9231 & 17.631 & 17.400 & 0.26766 \\
\hline 12 & $5 / 9 / 2002$ & $5 / 19 / 2002$ & 10 & 20.520 & 0.073 & 0.9296 & 15.366 & 15.300 & 0.18576 \\
\hline 13 & $6 / 14 / 2002$ & $6 / 24 / 2002$ & 10 & 8.900 & 0.187 & 0.8294 & 3.767 & 3.490 & 0.55495 \\
\hline 14 & $7 / 14 / 2002$ & $7 / 24 / 2002$ & 10 & 5.610 & 0.187 & 0.8294 & 2.323 & 2200 & 0.08448 \\
\hline 15 & $8 / 13 / 2002$ & $8 / 24 / 2002$ & 11 & 5.900 & 0.044 & 0.9570 & 4.659 & 4.630 & 0.03184 \\
\hline 16 & $9 / 16 / 2002$ & $9 / 26 / 2002$ & 10 & 8.700 & 0.163 & 0.8496 & 4.157 & 3.850 & 0.47600 \\
\hline 17 & $2 / 5 / 2003$ & $2 / 17 / 2003$ & 12 & 25.900 & 0.089 & 0.9148 & 17.865 & 16.600 & 0.83558 \\
\hline 18 & $6 / 2 / 2003$ & $6 / 15 / 2003$ & 13 & 7.680 & 0.151 & 0.8513 & 3.989 & 3.430 & 0.39350 \\
\hline 19 & $7 / 13 / 2003$ & $7 / 23 / 2003$ & 10 & 5.000 & 0.130 & 0.8781 & 2.642 & 2.610 & 0.09408 \\
\hline 20 & $8 / 16 / 2003$ & $8 / 26 / 2003$ & 10 & 5.320 & 0.113 & 0.8932 & 3.177 & 3.020 & 0.09246 \\
\hline 21 & $9 / 11 / 2003$ & $9 / 21 / 2003$ & 10 & 7.610 & 0.112 & 0.8940 & 4.786 & 4.350 & 0.32029 \\
\hline 22 & $1 / 28 / 2004$ & $2 / 10 / 2004$ & 13 & 24.000 & 0.093 & 0.9112 & 16.064 & 15.800 & 0.21298 \\
\hline 23 & $4 / 14 / 2004$ & $4 / 24 / 2004$ & 10 & 9.810 & 0.169 & 0.8445 & 4.732 & 4.210 & 0.64953 \\
\hline 24 & $6 / 8 / 2004$ & $6 / 20 / 2004$ & 12 & 7.890 & 0.199 & 0.8196 & 3.133 & 2.390 & 0.55975 \\
\hline 25 & $7 / 5 / 2004$ & $7 / 15 / 2004$ & 10 & 4.350 & 0.131 & 0.8772 & 2.308 & 2.260 & 0.05807 \\
\hline 26 & 8/7/2004 & $8 / 17 / 2004$ & 10 & 5.180 & 0.135 & 0.8737 & 2.987 & 2.640 & 0.28374 \\
\hline 27 & $9 / 20 / 2004$ & $9 / 30 / 2004$ & 10 & 5.310 & 0.099 & 0.9057 & 3.522 & 3240 & 0.19442 \\
\hline 28 & $10 / 1 / 2004$ & $10 / 12 / 2004$ & 11 & 9.610 & 0.186 & 0.8303 & 4.364 & 3.470 & 0.77484 \\
\hline 29 & $12 / 5 / 2004$ & $12 / 15 / 2004$ & 10 & 9.990 & 0.183 & 0.8328 & 4.695 & 4.000 & 0.61960 \\
\hline 30 & $2 / 11 / 2005$ & $2 / 22 / 2005$ & 11 & 21.440 & 0.069 & 0.9333 & 15.394 & 15.200 & 0.16657 \\
\hline 31 & $4 / 16 / 2005$ & $4 / 27 / 2005$ & $\|$ & 9.860 & 0.163 & 0.8496 & 4.680 & 4.035 & 0.52065 \\
\hline 32 & $6 / 15 / 2005$ & $6 / 27 / 2005$ & 12 & 7.650 & 0.132 & 0.8763 & 4.125 & 3.460 & 0.44897 \\
\hline 33 & $7 / 14 / 2005$ & $7 / 25 / 2005$ & $\|$ & 4.770 & 0.103 & 0.9021 & 2.783 & 2.710 & 0.04528 \\
\hline 34 & $8 / 16 / 2005$ & $8 / 27 / 2005$ & $\|$ & 4.800 & 0.160 & 0.8521 & 2.311 & 2.000 & 0.20811 \\
\hline 35 & $9 / 14 / 2005$ & $9 / 25 / 2005$ & $\|$ & 3.810 & 0.069 & 0.9333 & 2.750 & 2.610 & 0.11203 \\
\hline 36 & $10 / 12 / 2005$ & $10 / 22 / 2005$ & 10 & 6.690 & 0.109 & 0.8967 & 3.896 & 3.880 & 0.04045 \\
\hline 37 & $11 / 16 / 2005$ & $11 / 26 / 2005$ & 10 & 9.990 & 0.166 & 0.8470 & 4.829 & 4.360 & 0.47978 \\
\hline 38 & $2 / 3 / 2006$ & $2 / 13 / 2006$ & 10 & 19.990 & 0.066 & 0.9361 & 15.303 & 14.900 & 0.33240 \\
\hline 39 & $4 / 18 / 2006$ & $5 / 1 / 2006$ & 13 & 9.720 & 0.099 & 0.9057 & 5.499 & 5.115 & 0.35366 \\
\hline 40 & $6 / 6 / 2006$ & $6 / 17 / 2006$ & $\|$ & 6.550 & 0.144 & 0.8659 & 3.014 & 2.860 & 0.39406 \\
\hline 41 & $7 / 9 / 2006$ & $7 / 19 / 2006$ & 10 & 4.220 & 0.083 & 0.9204 & 2.787 & 2.790 & 0.02169 \\
\hline $\begin{array}{l}42 \\
43\end{array}$ & $\begin{array}{l}8 / 20 / 2006 \\
9 / 8 / 2006\end{array}$ & $\begin{array}{l}8 / 30 / 2006 \\
9 / 19 / 2006\end{array}$ & $\begin{array}{l}10 \\
11\end{array}$ & $\begin{array}{l}4.070 \\
3.210\end{array}$ & $\begin{array}{l}0.108 \\
0.121\end{array}$ & $\begin{array}{l}0.8976 \\
0.8860\end{array}$ & $\begin{array}{l}2.529 \\
1.793\end{array}$ & $\begin{array}{l}2.370 \\
1.650\end{array}$ & $\begin{array}{l}0.25791 \\
0.11828\end{array}$ \\
\hline 44 & $10 / 18 / 2006$ & $10 / 28 / 2006$ & 10 & 5.610 & 0.119 & 0.8878 & 3.375 & 3.090 & 0.20840 \\
\hline 45 & $4 / 7 / 2007$ & $4 / 20 / 2007$ & 13 & 8.880 & 0.099 & 0.9057 & 5.336 & 4.900 & 0.28482 \\
\hline 46 & $6 / 8 / 2007$ & $6 / 19 / 2007$ & $\|$ & 5.660 & 0.169 & 0.8445 & 2.636 & 2.430 & 0.25222 \\
\hline 47 & $7 / 15 / 2007$ & $7 / 25 / 2007$ & 10 & 3.900 & 0.113 & 0.8932 & 2.273 & 2.220 & 0.04620 \\
\hline 48 & $8 / 10 / 2007$ & $8 / 20 / 2007$ & 10 & 3.750 & 0.109 & 0.8967 & 2.239 & 2.170 & 0.06891 \\
\hline 49 & $10 / 10 / 2007$ & $10 / 20 / 2007$ & 10 & 4.900 & 0.120 & 0.8869 & 2.728 & 2.690 & 0.05748 \\
\hline 50 & $4 / 5 / 2008$ & $4 / 17 / 2008$ & 12 & 6.770 & 0.139 & 0.8702 & 3.642 & 3.160 & 0.36811 \\
\hline 51 & $5 / 12 / 2008$ & $5 / 22 / 2008$ & 10 & 9.590 & 0.139 & 0.8702 & 4.863 & 4.790 & 0.64913 \\
\hline 52 & $6 / 15 / 2008$ & $6 / 25 / 2008$ & 10 & 4.770 & 0.145 & 0.8650 & 2.621 & 2.490 & 0.37756 \\
\hline 53 & $7 / 20 / 2008$ & $8 / 2 / 2008$ & 13 & 3.650 & 0.087 & 0.9167 & 2.131 & 2.080 & 0.06435 \\
\hline 54 & $8 / 6 / 2008$ & $8 / 16 / 2008$ & 10 & 3.590 & 0.073 & 0.9296 & 2.498 & 2.490 & 0.05334 \\
\hline
\end{tabular}


Lampiran 1 (Lanjutan)

\begin{tabular}{|c|c|c|c|c|c|c|c|c|c|}
\hline $\mathrm{RC}$ & Awal & Akhir & Durasi (Hari) & $Q_{-} 0$ & $a$ & Konstanta rescosi & Q.06s & Q-ealeulated & RMSE \\
\hline 55 & $9 / 11 / 2008$ & $9 / 21 / 2008$ & 10 & 3.740 & 0.138 & $0.87 \|$ & 1.985 & 1.880 & 0.12853 \\
\hline 56 & $10 / 4 / 2008$ & $10 / 14 / 2008$ & 10 & 3.910 & 0.090 & 0.9139 & 2.553 & 2.490 & 0.10327 \\
\hline 57 & $11 / 8 / 2008$ & $11 / 18 / 2008$ & 10 & 7.690 & 0.133 & 0.8755 & 4.498 & 3.950 & 0.46786 \\
\hline 58 & $12 / 8 / 2008$ & $12 / 19 / 2008$ & $\|$ & 6.650 & 0.106 & 0.8994 & 3.762 & 3.715 & 0.04686 \\
\hline 59 & $1 / 9 / 2009$ & $1 / 20 / 2009$ & $\|$ & 9.890 & 0.167 & 0.8462 & 4.158 & 3.960 & 0.42493 \\
\hline 60 & $2 / 19 / 2009$ & $3 / 1 / 2009$ & 10 & 9.890 & 0.174 & 0.8403 & 4.823 & 4.140 & 0.76880 \\
\hline 61 & $3 / 16 / 2009$ & $3 / 28 / 2009$ & 12 & 9.500 & 0.088 & 0.9158 & 6.238 & 5.600 & 0.40199 \\
\hline 62 & $4 / 2 / 2009$ & $4 / 14 / 2009$ & 12 & 7.910 & 0.113 & 0.8932 & 4.423 & 4.020 & 0.32153 \\
\hline 63 & $5 / 22 / 2009$ & $6 / 1 / 2009$ & 10 & 9.690 & 0.183 & 0.8328 & 5.351 & 4.270 & 0.86259 \\
\hline 64 & $6 / 21 / 2009$ & $7 / 2 / 2009$ & $\|$ & 3.390 & 0.123 & 0.8843 & 2.215 & 1.830 & 0.26051 \\
\hline 65 & $7 / 10 / 2009$ & $7 / 21 / 2009$ & $\|$ & 3.250 & 0.087 & 0.9167 & 2.102 & 2.015 & 0.07698 \\
\hline 66 & $8 / 12 / 2009$ & $8 / 22 / 2009$ & 10 & 3.000 & 0.069 & 0.9333 & 2.269 & 2.120 & 0.11342 \\
\hline 67 & $9 / 20 / 2009$ & $9 / 30 / 2009$ & 10 & 3.150 & 0.124 & 0.8834 & 1.864 & 1.690 & 0.17204 \\
\hline 68 & $10 / 15 / 2009$ & $10 / 26 / 2009$ & $\|$ & 3.790 & 0.041 & 0.9598 & 3.036 & 3.025 & 0.02344 \\
\hline 69 & $11 / 15 / 2009$ & $11 / 25 / 2009$ & 10 & 5.980 & 0.191 & 0.8261 & 2.863 & 2.300 & 0.31082 \\
\hline 70 & $12 / 5 / 2009$ & $12 / 16 / 2009$ & $\|$ & 5.490 & 0.132 & 0.8763 & 3.008 & 2.665 & 0.22211 \\
\hline 71 & $1 / 3 / 2010$ & $1 / 13 / 2010$ & 10 & 9.550 & 0.133 & 0.8755 & 5.067 & 4.910 & 0.34157 \\
\hline 72 & $2 / 14 / 2010$ & $2 / 25 / 2010$ & $\|$ & 9.860 & 0.191 & 0.8261 & 4.351 & 3.460 & 0.77815 \\
\hline 73 & $4 / 15 / 2010$ & $4 / 27 / 2010$ & 12 & 5.710 & 0.155 & 0.8564 & 2.641 & 2.440 & 0.37937 \\
\hline 74 & $5 / 9 / 2010$ & $5 / 21 / 2010$ & 12 & 9.730 & 0.145 & 0.8650 & 4.856 & 4.395 & 0.68797 \\
\hline 75 & $6 / 10 / 2010$ & $6 / 20 / 2010$ & 10 & 3.950 & 0.133 & 0.8755 & 2.166 & 2.030 & 0.16195 \\
\hline 76 & $7 / 7 / 2010$ & $7 / 17 / 2010$ & 10 & 3.730 & 0.045 & 0.9560 & 2.988 & 2.980 & 0.02238 \\
\hline 77 & $8 / 16 / 2010$ & $8 / 27 / 2010$ & $\|$ & 2.710 & 0.045 & 0.9560 & 2.122 & 2.115 & 0.01406 \\
\hline 78 & $9 / 9 / 2010$ & $9 / 19 / 2010$ & 10 & 3.150 & 0.099 & 0.9057 & 2.071 & 1.920 & 0.10663 \\
\hline 79 & $10 / 17 / 2010$ & $10 / 27 / 2010$ & 10 & 4.550 & 0.081 & 0.9222 & 3.068 & 3.030 & 0.05168 \\
\hline 80 & $11 / 7 / 2010$ & $11 / 17 / 2010$ & 10 & 5.850 & 0.082 & 0.9213 & 3.888 & 3.880 & 0.17789 \\
\hline 81 & $12 / 14 / 2010$ & $12 / 24 / 2010$ & 10 & 3.610 & 0.109 & 0.8967 & 2.119 & 2.090 & 0.05960 \\
\hline & & Yin & 10 & 2.710 & 0.041 & 0.8196 & 1.793 & 1.650 & 0.01406 \\
\hline & & Yax & 14 & 37.710 & 0.199 & 0.9598 & 25.674 & 24.100 & 1.09571 \\
\hline & & Median & 10 & 6.690 & 0.113 & 0.8932 & 3.762 & 3.430 & 0.22653 \\
\hline & & Average & $\|$ & 9.185 & 0.118 & 0.8893 & 5.587 & 5.287 & 0.29126 \\
\hline
\end{tabular}


Lampiran 2. Peta bentuklahan SubDAS Wuryantoro

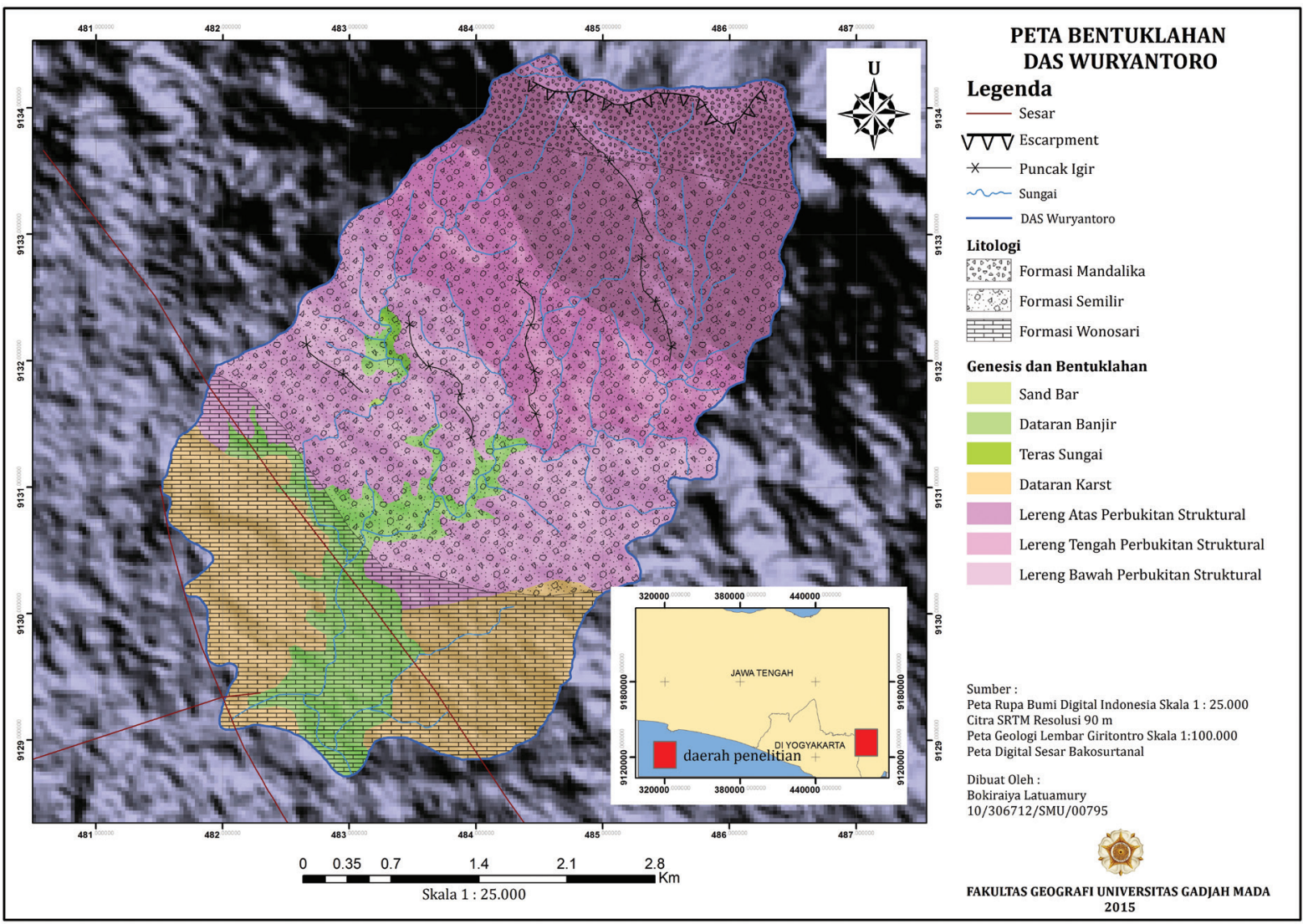

\section{SIMPULAN}

Bentuk kurva resesi individu memiliki variabilitas yang tinggi dapat diselesaikan menggunakan kurva resesi master, baik analisis kurva resesi master secara manual, maupun analisis kurva resesi master melalui proses evolusi dan solusi terbaik dari metode algoritma genetika. Hasil analisis kurva resesi master memperoleh optimalisasi parameter dan koefisien resesi untuk kurva resesi master secara algoritma genetika yang lebih akurat dibandingkan dengan kurva resesi secara manual. Bentuk kemiringan kurva resesi master yang secara grafis berbeda di SubDAS Wuryantoro cenderung memiliki bentuk kurva resesi yang lebih landai. Kemiringan kurva resesi landai merepresentasikan karakteristik resesi aliran dasar terutama kapasitas simpanan air yang optimal, tetapi kondisi penyimpanan aliran tetap dikontrol juga karakteristik akuifer batuan DAS penelitian. Hal ini terkait dengan suplai air ke tubuh sungai sebagai aliran dasar dipengaruhi oleh nilai porositas material penyusunnya. Porositas batuan sangat mempengaruhi imbuhan suatu sistem air tanah, sehingga besarnya tampungan air tanah sangat dipengaruhi oleh kondisi porositas batuan. Dalam proses pergerakan air secara vertikal, porositas memegang peranan penting dalam recharge airtanah.

\section{UCAPAN TERIMA KASIH}

Pada kesempataninipenulis mengucapkan banyak terima kasih kepada pimpinan dan staf Balai Penelitian dan Teknologi Pengelolaan Daerah Aliran Sungai (BPTPDAS) Surakarta, Kementerian Lingkungan Hidup dan Kehutanan atas kesempatan yang diberikan untuk mengumpulkan data sekunder berupa data debit harian selama kurun waktu penelitian untuk penyelesaian tulisan ini. 


\section{DAFTAR PUSTAKA}

Biswal, B., Kumar, D. N., 2013. A general geomorphological recession flow model for river basins. Water Resource Research. 49 (8), 4900-4906.

Biswal, B., Kumar, D.N., 2014. Study of dynamic behavior of recession curves. Hydrology Process. 28 (3), 784-792.

Biswal, B., Marani, M., 2010. Geomorphological origin of recession curves. Georaphy physics Research Lett. 37 (24), L24403. http://dx.doi. org/10.1029/2010g1045415.

Boussinesq, J., 1877. Essai sur la theorie des eaux courantes: du mouvemont non permanent des eaux souterraines. Academic Scientic Institute France. 23, 252-260.

Brutsaert, W., 2008. Long-term groundwater storage trends estimated from streamflow records: climatic perspective. Water Resource Research. 44 (2), W02409.

Carrillo, G., Troch, P.A., Sivapalan, M., Wagener, T., Harman, C., Sawicz, K., 2011. Catchment classification: hydrological analysis of catchment behavior through process-based modeling along a climate gradient. Hydroogy Earth System Scientic Discussion 8 (3).

Dupuit, J., 1863. Estudes thèoriques et pratiques sur le mouvement des eaux dans les

Gregor, M. and Malík, P., 2012. Construction of master recession curve using genetic algorithms. Journal of Hydrology Hydromech., 60(1), 3-15. Doi: 10.2478/v10098-012-0001-8
Gregor,S. and Malik, 2012. HydrOffice user manual version 2012. http:// hydrooffice.org

Maillet, E., 1905. Essai d'hydraulique souterraine et fluviale. Libraire Sci., A. Herman, Paris. (Cited by Hall (1968)

Shaw, S.B., McHardy, T.M., Riha, S.J., 2013. Evaluating the influence of watershed moisture storage on variations in base flow recession rates during prolonged rain-free periods in medium-sized catchments in New York and Illinois, USA.Water Resource Research. 49 (9), 6022-6028.

Smakhtin, VU., 2001. Low flow hydrology: a review. Journal of Hydrology; 240:147-86, doi: 10.1016/S00221694(00)00340-1.

Staudinger, M., Stahl, K., Seibert, J., Clark, M.P., Tallaksen, L.M., 2011. Comparison of hydrological model structures based on recession and low flow simulations. Hydroloy Earth System Science Discuss. 8 (4).

Stoelzle, M., Stahl, K., Weiler, M., 2012. Are streamflow recession characteristics really characteristic? Hydroloy Earth System Science.

Szilagyi, J., Gribovszki Z., Kalicz P., 2007. Estimation of catchment-scale evapotranspiration from base flow recession data: numerical model and practical application results. Journal of hydrology, 336:206-17, doi:10.1016/j.jhydrol.2007.01.004

Tallaksen LM., 1995. A review of base flow recession analysis. Journal of hydrology,165:349-70, doi:10.1016/0022-1694(94)02540-R. 